\title{
UČENJE SLOVENSKEGA JEZIKA TER STALIŠČA DIJAKOV IN STARŠEV DO SLOVENŠČINE V VARAŽDINSKI IN MEDŽIMURSKI ŽUPANIJI NA HRVAŠKEM
}

\author{
Mojca MEDVEŠEK \\ Inštitut za narodnostna vprašanja
}

Medvešek, M. (2017): Učenje slovenskega jezika ter stalǐ̌ča dijakov in staršev do slovenščine v Varaždinski in Medžimurski županiji na Hrvaškem. Slovenščina 2.o, 5 (2): 151-178. DOI: http://dx.doi.org/10.4312/slo2.0.2017.1.151-178.

V zadnjih petih letih so se v Varaždinski in Medžimurski županiji uresničile nove možnosti učenja slovenskega jezika $\mathrm{v}$ šolah. $\mathrm{V}$ prispevku obravnavamo pravne možnosti urejanja položaja slovenščine na Hrvaškem, uresničevanje možnosti učenja slovenščine v Varaždinski in Medžimurski županiji v praksi ter izsledke raziskav, opravljenih med dijaki dveh srednjih šol in njihovimi starši o učenju slovenskega jezika. Izsledki raziskav so med drugim pokazali, da imajo dijaki in starši do učenja slovenskega jezika pozitiven odnos. Znanje slovenščine jim pomeni zlasti večje možnosti za izobraževanje oziroma zaposlitev v Sloveniji. Pokazalo pa se je tudi, da je med učenci slovenskega jezika malo pripadnikov slovenske manjšine.

Ključne besede: slovenski jezik, Varaždinska županija, Medžimurska županija, Hrvaška, učenje manjšinskega jezika

\section{UVOD}

Zmanjševanja števila prebivalcev na Hrvaškem, ki se po narodni pripadnosti opredeljujejo kot Slovenci in še zlasti tistih, ki za materni jezik navajajo slovenščino, kot se kaže v popisih prebivalstva po letu $1971,{ }^{1}$ ni mogoče pripisati

\footnotetext{
${ }_{1}$ Na Hrvaškem se je ob popisu prebivalstva leta 1953 za slovensko narodno pripadnost opredelilo 43.010 prebivalcev, ob popisu leta 2011 pa le še 10.517. Še večji upad v številu je razviden iz kategorije materni jezik. Ob popisu leta 1991 je kot svoj materni jezik slovenščino (opomba se nadaljuje na naslednji strani)
} 
zgolj migracijskim ali demografskim dejavnikom. Slovenci, ki so v obdobju obstoja Socialistične federativne republike Jugoslavije (SFRJ) živeli na Hrvaškem, so imeli kot narod SFRJ pravice, tudi v povezavi z jezikom, ki so bile zapisane v Ustavi Socialistične Republike Hrvaške ${ }^{2}$ in v Ustavi SFRJ od leta 1963 naprej.3 Kljub formalnopravni enakopravnosti narodov in narodnosti, opredeljeni v republiški in federativni ustavi, se jezikovne pravice Slovencev na Hrvaškem v praksi večinoma niso uresničevale v skladu z zapisanim. Učenje slovenskega jezika $\mathrm{v}$ izobraževalnem sistemu se je izvajalo izjemoma in občasno, ${ }^{4}$ raba slovenskega jezika v javnosti ni bila zagotovljena, niti ni bila zaželena. Slovenščina se je govorila večinoma le v krogu družine in v kulturnih društvih. Slovenci, ki so živeli na območju Hrvaške v obdobju skupne države Jugoslavije, ohranjanju in razvoju slovenskega jezika niso namenjali velike pozornosti. To je bila delno tudi posledica razširjanja ideje o skupni jugoslovanski pripadnosti ter konceptu bratstva in enotnosti. Zaradi lažjega vključevanja v družbo in številnih etnično mešanih zakonov se je tudi na ravni družine pogosto - predvsem $\mathrm{v}$ komuniciranju $\mathrm{z}$ otroki - opuščala raba slovenskega jezika.

Odnos slovenske skupnosti do slovenskega jezika in etnične identitete se je začel spreminjati $\mathrm{z}$ razpadom Jugoslavije in nastankom novih držav. Sprememba se odraža predvsem v povečanju števila slovenskih kulturnih društev in v aktivnejšem angažiranju oziroma delovanju slovenske manjšine na področju učenja in ohranjanja slovenskega jezika. Zlasti po letu 2000 se je začelo krepiti društveno samoorganiziranje slovenske skupnosti, 5 ki je začela $\mathrm{v}$

navedlo 19.341 prebivalcev Hrvaške, leta 2011 pa je slovenščino kot materni jezik navedlo zgolj 9.220 prebivalcev (Državni zavod za statistiko Republike Hrvaške 2011).

${ }^{2} \mathrm{Na}$ primer 137. in 138. člen Ustave Socialistične republike Hrvaške (1974).

3 V Ustavi SFRJ iz leta 1963 so bile pravice v zvezi z rabo jezika navedene v 41., 42. in 43. členu. V Ustavi SFRJ iz leta 1974 pa v členih 171, 243, 246 in 247.

$4 \mathrm{Na}$ Hrvaškem sta krajše obdobje delovala dva šolska oddelka, v katerih je bil učni jezik slovenščina. En oddelek je bil oblikovan leta $1947 \mathrm{v}$ osnovni šoli v Labinu in je deloval eno šolsko leto, drugi oddelek pa je tri leta (1950-1953) deloval v osnovni šoli na Reki (Riman 2013: 372; Koprivc 2016: 66).

5 Od leta 1992 kulturna društva Slovencev na Hrvaškem delujejo v okviru krovne organizacije (opomba se nadaljuje na naslednji strani) 
večji meri uresničevati obstoječe možnosti na področju družbene (kulturne) in politične participacije. Poleg več novonastalih kulturnih društev je slovenska skupnost izvolila tudi svoje svete in predstavnike v lokalni samoupravi. Kljub temu Slovenci na Hrvaškem marsikje še vedno ne izkoristijo vseh obstoječih možnosti aktivnejšega sooblikovanja družbene stvarnosti. Spodbudno pa je, da je v zadnjih letih slovenska skupnost v nekaterih županijah izboljšala možnosti za učenje slovenskega jezika.

Na Hrvaškem je še vedno najpogostejša in najbolj razširjena oblika učenja slovenskega jezika organizirana $\mathrm{v}$ obliki tečajev, ki jih izvajajo slovenska kulturna društva samostojno ali v obliki dopolnilnega pouka slovenskega jezika (DPS). ${ }^{6}$ To ne velja za Varaždinsko županijo, v kateri Slovensko kulturno društvo Nagelj nima močne tradicije izvajanja tečajev slovenskega jezika, in Medžimursko županijo, v kateri slovenska skupnost niti ni ustanovila društva. V teh dveh županijah je učenje slovenščine organizirano drugače in poteka na šolah kot obšolska dejavnost oziroma $\mathrm{v}$ okviru izobraževalnega sistema. Raziskava, izvedena leta 2013 med učenci osnovnih šol Varaždinske županije, ki so se učili slovenščino v okviru obšolske dejavnosti, in njihovimi starši, 7 je pokazala, da je prvi oziroma materni jezik velike večine staršev in otrok hrvaščina in ne slovenščina, velika večina se jih je opredelila za hrvaško narodno pripadnost, za učenje slovenščine pa so motivirani zaradi različnih razlogov - od želje po znanju več jezikov, povezav s Slovenijo (sorodstvenih vezi

\footnotetext{
Zveze Slovencev v Republiki Hrvaški, ki se je leta 1996 preimenovala v Zvezo slovenskih društev na Hrvaškem. Trenutno Zveza slovenskih društev na Hrvaškem, ki ima sedež v Zagrebu, združuje 16 kulturnih društev. Poleg Kulturnega prosvetnega društva Slovenski dom v Zagrebu, ki deluje od leta 1929, in Slovenskega doma, kulturno prosvetnega društva Bazovica na Reki, ki deluje od leta 1947, sta 2 društvi nastali v obdobju od leta 1990 in 2000, 12 društev pa je nastalo po letu 2000.

${ }^{6}$ V skladu z Zakonom o odnosih Republike Slovenije s Slovenci zunaj njenih meja (2006) Ministrstvo za izobraževanje, znanost in šport Republike Slovenije v sodelovanju s slovenskimi kulturnimi društvi, veleposlaništvi Republike Slovenije v tujini in z Uradom vlade Republike Slovenije za Slovence v zamejstvu in po svetu organizira dopolnilni pouk slovenskega jezika in kulture po svetu (DPS).

7 Raziskava je potekala pri projektu Perspektive učenja slovenskega jezika v osnovnih šolah Varaždinske županije (2013), ki ga je sofinanciral Urad vlade Republike Slovenije za Slovence $\mathrm{v}$ zamejstvu in svetu.
} 
in prijateljev v Sloveniji), življenja na obmejnem območju, nadaljevanja šolanja v Sloveniji, večjih možnosti za zaposlitev v Sloveniji itd. Izsledki te raziskave niso kazali na to, da se učenja slovenskega jezika v večjem številu udeležujejo pripadniki slovenske skupnosti oziroma učenci, ki imajo slovensko ozadje. Te ugotovitve so nas spodbudile, da smo raziskovalno poiskali tudi odgovor na vprašanje, ali je situacija podobna med dijaki, ki se v Varaždinski in Medžimurski županiji slovenski jezik učijo na ravni srednje šole. V nadaljevanju prispevka bomo predstavili, kakšna je struktura dijakov, ki se učijo slovenščino, in njihovih staršev ter kakšna so njihova stališča do učenja in rabe slovenščine.

\section{PRAVNI OKVIR UREJANJA POLOŽAJA SLOVENSKEGA JEZIKA NA HRVAS̆KEM}

$\mathrm{Z}$ razpadom SFRJ in nastankom novih držav se je odprlo vprašanje statusa slovenske skupnosti in drugih narodnih manjšin na Hrvaškem. Eden izmed pogojev mednarodne skupnosti, da Hrvaško prizna kot samostojno državo, je bil prav ureditev položaja narodnih manjšin. Model zaščite narodnih manjšin, ki ga je Republika Hrvaška podedovala iz obdobja skupne jugoslovanske države in se je nanašal na Madžare, Italijane, Čehe, Slovake, Rusine in Ukrajince, v novonastali državi ni bil vprašljiv. Izziv je predstavljala ureditev pravic narodnih manjšin, ki so imele prej status narodov SFRJ (Tatalović 2001: 96; Tatalović in Lacović 2011: 379).

Slovenci na Hrvaškem so ena izmed $22 \mathrm{v}$ ustavi navedenih narodnih manjšin. Njihov položaj je opredeljen v Ustavi Republike Hrvaške (1990), v Ustavnem zakonu o pravicah narodnih manjšin (2002) in v drugih področnih zakonih. ${ }^{8}$

\footnotetext{
8 Temelji za rabo manjšinskih jezikov so bili zapisani leta 1990 v Ustavi Republike Hrvaške, kjer so bili med drugim zagotovljeni svobodno izražanje narodne pripadnosti, raba lastnega jezika in pisave ter kulturna avtonomija (Tatalović 2005: 31). Leta 1992 je hrvaški sabor sprejel Ustavni zakon o človekovih pravicah in svoboščinah in pravicah narodnih in etničnih skupnosti ali manjšin v Republiki Hrvaški, ki je zagotavljal možnost institucionalizirane pravice do kulturne avtonomije manjšin. Ker pa je njegovo sprejemanje potekalo pod pritiski mednarodne skupnosti, v določenih okoljih ni bilo politične volje, da bi se sprejeta določila uresničevala tudi v praksi (Tatalović 2001: 96). Pozitivnejša družbena klima v odnosu do (opomba se nadaljuje na naslednji strani)
} 
Varstvo pravic narodne manjšine je v veliki meri odgovornost države, $\mathrm{v}$ kateri manjšina živi, $\mathrm{v}$ podporo pri ohranjanju manjšinskih jezikovnih in kulturnih značilnosti pa je tudi izvorna država (Slovenija) ${ }^{9}$ s svojo zakonodajo in ukrepi ter bilateralnimi dogovori. ${ }^{10}$ Slovenska manjšina zaradi maloštevilnosti oziroma prostorske razpršenosti ne dosega $\mathrm{v}$ zakonodaji opredeljene številčne ravni za uresničevanje določenih manjšinskih pravic, kot je na primer raba manjšinskega jezika kot uradnega jezika. Za ohranjanje in razvoj slovenskega jezika pa je pomemben 11. člen Ustavnega zakona o pravicah narodnih manjšin na Hrvaškem, ki določa, da se »vzgoja in izobraževanje pripadnikov narodnih manjšin izvaja v predšolskih ustanovah, osnovnih in srednjih šolah v njihovem jeziku in pisavi«. Omeniti velja še 15. člen Ustavnega zakona o pravicah narodnih manjšin, v katerem piše, da imajo "pripadniki manjšin možnost ustanovitve kulturnih društev, knjižnične, arhivske in znanstvene aktivnosti z namenom ohranjanja, razvoja in izkazovanja svoje kulturne identitete«, ter 18. člen, ki govori o pravici narodne manjšine do lastnih medijev (tisk, radio in televizija) ter o vključevanju za manjšino (in tudi večino) relevantnih vsebin (tudi v manjšinskem jeziku) v nacionalne, regionalne in lokalne medije (Ustavni

urejanja položaja narodnih manjšin na Hrvaškem in do uresničevanja zakonsko opredeljenih pravic se je oblikovala šele po letu 2000 (Tatalović 2005: 19-20), ko je bil v procesu priključevanja Hrvaške Evropski uniji leta 2002 sprejet nov Ustavni zakon o pravicah narodnih manjšin na Hrvaškem.

9 Republika Slovenija obravnava Slovence na Hrvaškem, ki živijo ob obmejnem pasu, zlasti v Istri, Gorskem Kotarju in Medžimurju (Resolucija o položaju avtohtonih slovenskih manjšin v sosednjih državah in s tem povezanimi nalogami državnih in drugih dejavnikov Republike Slovenije 1996) oziroma v sedmih županijah Republike Hrvaške, ki mejijo na Republiko Slovenijo, in na območju mesta Zagreb (Zakon o odnosih Republike Slovenije s Slovenci zunaj njenih meja 2006), kot avtohtono narodno manjšino, Slovence, ki živijo na ostalih območjih Hrvaške, pa kot izseljensko skupnost.

V Ustavi Republike Slovenije (1991) je v 5. členu navedeno, da »država /.../. Skrbi za avtohtone slovenske narodne manjšine $\mathrm{v}$ sosednjih državah, za slovenske izseljence in zdomce, ter pospešuje njihove stike $\mathrm{z}$ domovino. « Poleg tega položaj slovenske manjšine zunaj Slovenije urejajo Zakon o odnosih Slovenije s Slovenci zunaj njenih meja (2006) in programski dokumenti, kot sta Resolucija o položaju avtohtonih slovenskih manjšin $\mathrm{v}$ sosednjih državah in s tem povezanimi nalogami državnih in drugih dejavnikov Republike Slovenije (1996) ter Strategija odnosov Republike Slovenije s Slovenci zunaj njenih meja (2016).

${ }^{10} \mathrm{Na}$ primer: Zakon o ratifikaciji Sporazuma o sodelovanju v kulturi in izobraževanju med Vlado Republike Slovenije in Vlado Republike Hrvaške (1994).

(opomba se nadaljuje na naslednji strani) 
zakon o pravicah narodnih manjšin, 2002).

Podrobneje so možnosti, ki jih imajo narodne manjšine na Hrvaškem glede učenja in rabe manjšinskih jezikov, $\mathrm{v}$ vzgojno-izobraževalnem sistemu opredeljene še v Zakonu o uporabi jezika in pisave narodnih manjšin (2000), Zakonu o vzgoji in izobraževanju v jeziku in pisavi narodnih manjšin (2000), Zakonu o predšolski vzgoji in izobraževanju (1997), Zakonu o vzgoji in izobraževanju v osnovni in srednji šoli (2008) ter Zakonu o učbenikih v osnovni in srednji šoli (2010).

V skladu z zakonodajo je Ministrstvo za znanost, izobraževanje in šport Republike Hrvaške za raven osnovne in srednje šole razvilo tri modele ter posebne oblike izobraževanja ${ }^{11}$ za narodne manjšine: 1 . model A - učni jezik v šoli je jezik narodne manjšine, kar pomeni, da pouk poteka $\mathrm{v}$ jeziku in pisavi narodnih manjšin, obvezno pa je učenje hrvaškega jezika; 2. model B dvojezično izobraževanje, kar pomeni, da pouk poteka $\mathrm{v}$ hrvaškem jeziku in $\mathrm{v}$ jeziku narodne manjšine; 3 . model $\mathrm{C}$ - jezik manjšine se poučuje kot ocenjevan izbirni predmet (manjšinskega jezika se učenci učijo $2-5$ šolskih ur na teden, kar vključuje tudi spoznavanje manjšinske književnosti, geografije, zgodovine, glasbe in likovne umetnosti), učni jezik učencev v šoli pa je hrvaščina.

Narodne manjšine lahko same izberejo model izobraževanja, ki mora biti v skladu z možnostmi (ustrezna udeležba pri izvajanju programa) in izkazanim interesom narodne manjšine. ${ }^{12} \mathrm{~V}$ skladu z že predstavljeno hrvaško in tudi slovensko zakonodajo imajo pripadniki slovenske manjšine na Hrvaškem na

\footnotetext{
${ }_{11}$ Med posebne oblike pouka se štejejo: poletna ali zimska šola, pouk na daljavo (dopisni pouk), obstajajo pa tudi posebni programi za vključevanje romskih učencev v vzgojnoizobraževalni sistem.

${ }^{12}$ Izvajanje programov v manjšinskih jezikih je odvisno od interesa posamezne manjšine, zato se podatki spreminjajo vsako šolsko leto. V šolskem letu 2014/15 se je model A izvajal za češko, madžarsko, srbsko in italijansko narodno manjšino, po modelu B so se izobraževali pripadniki češke, madžarske in srbske narodne manjšine, po modelu C pa so se izobraževali pripadniki albanske, avstrijske, češke, madžarske, makedonske, nemške, poljske, ruske, rusinske, slovaške, slovenske, srbske, ukrajinske in judovske narodne manjšine (Vlada Republike Hrvaške 2015).
} 
razpolago različne oblike učenja slovenščine:

- možnosti učenja slovenščine na ravni predšolske vzgoje,

- učenje slovenščine v okviru javnega izobraževalnega sistema - kot izbirni predmet ali kot fakultativni predmet na ravni srednje šole ali kot izbirni predmet po modelu $\mathrm{C}$ - jezik manjšine na ravni osnovne in srednje šole,

- učenje slovenščine kot obšolske dejavnosti (na osnovnih šolah) v okviru različnih projektov,

- učenje slovenščine $\mathrm{v}$ obliki tečajev, ki se izvajajo pod okriljem slovenskih kulturnih društev oziroma dopolnilnega pouka slovenskega jezika (DPS) in so namenjeni tako mladim kot starejšim ter na visokošolski ravni izobraževalnega sistema.

Uresničevanje pravice do učenja manjšinskega jezika $\mathrm{v}$ šolskem sistemu $\mathrm{v}$ praksi pogosto ni enostavno, saj mora istočasno obstajati močan interes manjšinske skupnosti, vodstva šole, na kateri bi se pouk izvajal, lokalne skupnosti in političnih akterjev. Pogost argument za neuresničitev učenja slovenskega jezika $\mathrm{v}$ javnem vzgojno-izobraževalnem sistemu, kljub izkazanemu interesu otrok in staršev, je pomanjkanje vzgojiteljskega oziroma učiteljskega kadra z znanjem slovenskega jezika.

\section{3 ŠTEVILČNOST IN ORGANIZIRANOST SLOVENSKE SKUPNOSTI V VARAŽDINSKI IN MEDŽIMURSKI ŽUPANIJI}

Pri popisu leta 2011 se je v Varaždinski županiji, ki je imela 175.951 prebivalcev, za slovensko narodnost opredelilo 496 prebivalcev (o,3 \%), medtem ko je slovenščino kot materni jezik navedlo 505 prebivalcev (Državni zavod za statistiko Republike Hrvaške 2011). Podobno visok delež prebivalcev, ki se opredeljujejo za Slovence, živi tudi v Medžimurski županiji. Po popisnih podatkih iz leta 2011 je imela Medžimurska županija 113.804 prebivalcev, za slovensko narodnost se je opredelilo 516 prebivalcev (o,4 \%), medtem ko je slovenščino kot materni jezik navedlo 554 prebivalcev (o,5 \%) (Državni zavod 
za statistiko Republike Hrvaške 2011).

Delež Slovencev $\mathrm{v}$ obeh županijah je podoben, obstajajo pa razlike $\mathrm{v}$ organiziranosti in delovanju slovenske skupnosti med Varaždinsko in Medžimursko županijo. Slovenci v Varaždinski županiji so dokaj dobro organizirani, od leta 2004 imajo Hrvaško-slovensko društvo prijateljstva, od leta 2008 pa še Slovensko kulturno društvo Nagelj. ${ }^{13}$ Aktivni so tudi na področju politične participacije.14 Leta 2007 so ustanovili Svet slovenske narodne manjšine Varaždinske županije. ${ }^{15} \mathrm{Na}$ drugi strani pa Slovenci v Medžimurski županiji nimajo svojega društva ali sveta. ${ }^{16}$ Spodbudno je, da so v Medžimurski županiji na volitvah leta 2015 dobili pravico do manjšinskih volitev zaradi večjega števila prebivalcev, ki so se opredelili kot Slovenci (več kot 500). Prvič je bil izvoljen predstavnik slovenske manjšine na ravni občine Štrigova. ${ }^{17}$ Župan občine Štrigova je to komentiral z besedami: »Morda se počutijo bolj svobodne in so se opredelili kot manjšina /prevod avt./« (Beti 2015). Kljub majhnemu napredku na področju politične participacije za slovensko skupnost na Hrvaškem še vedno velja, da imajo zelo majhno število

13 Društvo ima ob upoštevanju različnih virov 48 (Združenje slovenska izseljenska matica 2016) oziroma 66 članov (Žitnik Serafin 2014: 154).

14 Na petih manjšinskih volitvah leta 2015 je slovenska manjšina na Hrvaškem dobila 9 svetov, in sicer 4 svete na ravni županije (Primorsko-goranska, Splitsko-dalmatinska, Istrska in Mesto Zagreb), 4 svete na ravni mesta (Reka, Split, Pulj in Umag) in 1 svet na ravni občine (Matulji). Izvoljenih je bilo tudi 14 predstavnikov, in sicer 5 predstavnikov na ravni županije (Karlovška, Varaždinska, Zadrska, Osiješko-Baranjska in Šibeniško-Kninska), 7 predstavnikov na ravni mesta (Samobor, Karlovec, Varaždin, Opatija, Zadar, Osijek in Poreč) in 2 predstavnika na ravni občine (Cestica in Štrigova) (Izbori 2015 za članove vijeća i predstavnike nacionalnih manjina 2015).

${ }_{15} \mathrm{Na}$ manjšinskih volitvah leta 2007 se je od 380 volivcev slovenske manjšine v Varaždinski županiji volitev udeležilo 12 volivcev (3,6 \%). Izvolili so Svet slovenske narodne manjšine v Varaždinski županiji. V statutu Sveta slovenske narodne manjšine Varaždinske županije je zapisano, da je to institut manjšinske samouprave na območju Varaždinske županije (Škiljan 2015: 96). Na zadnjih volitvah leta 2015 v Varaždinski županiji zaradi zmanjšanja števila prebivalcev, ki so se opredelili kot Slovenci, pod $500 \mathrm{v}$ skladu z veljavno zakonodajo niso mogli izvoliti sveta na ravni regije, temveč samo predstavnika.

16 Brez slovenskih kandidatov oziroma list so tako minile volitve leta 2015 v KrapinskoZagorski, Medžimurski, Bjelovarsko-Bilogorski, Dubrovniško-Neretvanski, Siško-Moslavaški in Zagrebški županiji, v mestu Buje in v občini Hum na Sotli (JPT 2015: 15; Izbori 2015 za članove vijeća i predstavnike nacionalnih manjina 2015).

17 Od 66 volivcev s pravico glasovanja v občini Štrigova se je volitev udeležil 1 sam prebivalec občine. 
posameznikov, ki bi bili pripravljeni kandidirati na manjšinskih volitvah, hkrati pa je na teh volitvah udeležba zelo slaba.

\section{MOŽNOSTI UČENJA SLOVENŠČINE V VARAŽDINSKI IN MEDŽIMURSKI ŽUPANIJI}

Pripadniki slovenske manjšine na Hrvaškem imajo formalnopravno zagotovljeno možnost učenja slovenščine praktično na celotni izobraževalni vertikali, vendar te možnosti v marsikateri županiji ne izkoristijo.

Učenje slovenščine na ravni predšolske vzgoje v Varaždinski in Medžimurski županiji ni omogočeno. Se pa dogaja, da otroci iz obmejnih krajev iz Varaždinske ali Medžimurske županije zaradi infrastrukturnih težav v lokalni skupnosti ali drugih pragmatičnih razlogov obiskujejo vrtce v Sloveniji.

Na ravni osnovne šole so se učenci v šolskem letu 2007/o8 lahko učili slovenski jezik na osnovni šoli Štrigova v Medžimurju, in sicer po modelu C. Pouk slovenščine je obiskovalo 6 učencev. Že naslednje šolsko leto šola ni več omogočila učenja slovenščine, saj naj ne bi bilo izkazanega interesa med učenci; kljub temu pa posamezni učenci iz tega šolskega okraja obiskujejo osnovno šolo v Sloveniji (MZOS 2009; Mesarić 2010: 9; Mesarić 2012: 10-11). V Sloveniji otrok ne šolajo samo posamezniki, ki se opredeljujejo kot Slovenci oziroma imajo tam sorodnike, temveč tudi Hrvati, pri katerih je to zaradi bližine meje tradicija oziroma vidijo $\mathrm{v}$ šolanju $\mathrm{v}$ Sloveniji prednosti za nadaljnje izobraževalne in zaposlitvene priložnosti otrok. Na drugi strani pa del prebivalcev občine Štrigova šolanja otrok v Sloveniji ne sprejema pozitivno in na to gledajo kot na izgubo hrvaške narodne identitete ter slabljenje hrvaškega jezika. Staršev otrok, ki bi si želeli učenja slovenskega jezika v hrvaških šolah, je več, kot se zdi na prvi pogled, se pa mnogi med njimi ne želijo izpostaviti, saj menijo, da posledično obstajajo možnosti negativnih pritiskov na njihove otroke (Medvešek in Riman 2018). Pripadniki slovenske manjšine občasno izrazijo željo, da bi se v osnovni šoli Štrigova uvedel pouk slovenskega jezika. Leta 2013 je bila izvedena anketa, v kateri je 25 staršev izjavilo, da bi svoje 
otroke vključili k pouku slovenščine. Pobuda je bila posredovana Medžimurski županiji, tam pa naj bi se zataknilo pri iskanju primernega kadra za pouk slovenskega jezika (Beti 2015). Še bolj spodbudni podatki o obstoječem interesu za učenje slovenščine so bili prikazani, ko je julija 2014 minister Urada Vlade Republike Slovenije za Slovence v zamejstvu in po svetu obiskal Medžimursko županijo. Na tem delovnem sestanku so bili predstavljeni rezultati ankete, izvedene v Medžimurski županiji, v kateri je kar 551 učencev in 5 učiteljev pokazalo interes za učenje slovenščine (Međimurska županija 2014). Na podlagi izkazanega interesa naj bi se v bližnji prihodnosti tudi v Medžimurski županiji učenci lahko učili slovenski jezik in kulturo na štirih osnovnih šolah: $v$ Murskem Središču, Selnici, Štrigovi in Sv. Martinu. Na eni izmed omenjenih osnovnih šol bodo organizirali še pouk za srednješolce. Zdi se, da bo učenje slovenščine organizirano na enak način kot projekt Poučevanje slovenščine in slovenske kulture v Varaždinski županiji, ki ga financira Republika Slovenija (Međimurska županija 2017).

V Varaždinski županiji učenje slovenščine na ravni osnovne šole ne poteka po modelu C, s čimer bi bil slovenski jezik del javnega šolskega predmetnika, temveč se od šolskega leta 2012/13 izvaja v okviru že omenjenega projekta Poučevanje slovenščine in slovenske kulture $\mathrm{v}$ Varaždinski županiji, ki je organiziran in financiran prek Ministrstva za izobraževanje, znanost in šport Republike Slovenije. 8 učiteljic iz obmejnih slovenskih šol izvaja učenje slovenskega jezika kot obšolske dejavnosti v 12 osnovnih šolah Varaždinske županije. ${ }^{18}$ Učenje slovenskega jezika poteka po učnem načrtu, ki so ga pripravile učiteljice in ga je potrdilo Ministrstvo za znanost, izobraževanje in šport Republike Hrvaške. Pouk slovenščine se izvaja v prostorih šol, vendar ni del rednih šolskih dejavnosti in ni ocenjevan. V prvem letu je dopolnilni pouk obiskovalo okoli 240 učencev, v šolskem letu 2016/17 pa je bilo k pouku

${ }_{18}$ Delo učiteljic financira Ministrstvo za izobraževanje, znanost in šport Republike Slovenije, pouk pa se izvaja v prostorih osnovnih šol. Koordinator projekta je osnovna šola Videm pri Ptuju. 
vpisanih 144 učencev.

Na ravni srednje šole se v Varaždinski županiji izvaja učenje slovenskega jezika po modelu C. Na predlog Sveta slovenske nacionalne manjšine Varaždinske županije ter v sodelovanju z Ministrstvom za znanost, izobraževanje in šport Republike Hrvaške, Zvezo slovenskih kulturnih društev in Upravnim oddelkom za šolstvo Varaždinske županije so v šolskem letu 2011/12 na Drugi gimnaziji Varaždin začeli z izvajanjem izbirnega predmeta slovenski jezik in kultura. Druga gimnazija Varaždin je postala prva srednja šola na Hrvaškem, v kateri je slovenščina del rednega učnega programa (po modelu C). V prvem letu učenja slovenskega jezika je pouk obiskovalo 64 dijakov (MZOS 2012), v šolskem letu 2016/17 pa 52 dijakov. Slovenščino se kot fakultativni predmet lahko učijo tudi dijaki Prve gimnazije Varaždin.

V šolskem letu 2015/16 se je pouk slovenščine začel tudi v Srednji šoli v Čakovcu, ki je v Medžimurski županiji. Pouk slovenščine ne poteka po modelu $\mathrm{C}$, ki je pravzaprav model učenja jezika, ki je namenjen narodni manjšini, temveč je bila slovenščina najprej organizirana samo kot fakultativni predmet, naslednje šolsko leto pa še kot izbirni predmet. Slovenščino v obeh srednjih šolah, torej $\mathrm{v}$ Varaždinski in Medžimurski županiji, poučuje isti učitelj slovenskega jezika, ki je tudi pripravil učni načrt za poučevanje slovenščine. Prvo leto je slovenščino kot fakultativni predmet obiskovalo okoli 20 učencev. V šolskem letu 2016/17 pa se je učenje slovenskega jezika začelo poučevati kot izbirni (15 učencev) in kot fakultativni predmet (15 učencev) (Srednja šola Čakovec 2016: 23, 40).

\section{METODOLOGIJA RAZISKAVE MED DIJAKI IN STARS̆I V VARAŽDINSKI IN MEDŽIMURSKI ŽUPANIJI}

Med dijaki, ki se na Drugi gimnaziji Varaždin slovenščino učijo po modelu C, in dijaki Srednje šole Čakovec, ki se slovenščino učijo kot fakultativni in izbirni predmet, ter njihovimi starši smo $\mathrm{v}$ dveh časovnih točah izvedli anketo, $\mathrm{s}$ pomočjo katere smo želeli ugotoviti: kdo so dijaki, ki obiskujejo pouk 
slovenskega jezika (ali gre za pripadnike slovenske manjšine ali so se za učenje slovenskega jezika odločili tudi drugi); ali je slovenščina za te dijake prvi ali drugi/tuji jezik; zakaj so se starši oziroma dijaki odločili za učenje slovenskega jezika; kakšna je raba slovenskega jezika $\mathrm{v}$ družini in zunaj družine itd. Pripravili smo dva strukturirana vprašalnika, enega za dijake in enega za starše, z vprašanji zaprtega in odprtega tipa. Dijaki so anketo v slovenskem jeziku izpolnjevali pri pouku slovenskega jezika. Starši pa so anketo izpolnjevali doma, pri čemer so lahko sami izbrali, ali bodo izpolnili anketo v slovenskem ali hrvaškem jeziku.

Pri raziskavi, ${ }^{19}$ ki smo jo izvedli leta 2014 na Drugi gimnaziji Varaždin, je med 45 dijaki, ki so obiskovali pouk slovenskega jezika, anketo izpolnilo 41 dijakov in 39 staršev.

Pri raziskavi,20 izvedeni leta 2017 na Srednji šoli v Čakovcu, pa je v anketi sodelovalo 25 dijakov od približno 30 dijakov, ki se učijo slovenski jezik, in 18 staršev.

19 Raziskava je potekala pri projektu Promocija učenja slovenskega jezika v Varaždinski županiji (2014), ki ga je financiral Urad vlade za Slovence v zamejstvu in svetu Republike Slovenije.

${ }_{20}$ Raziskava, v okviru katere smo naredili anketo med dijaki in starši ter intervjuje s pripadniki slovenske skupnosti, je potekala pri projektu Priložnosti in možnosti za ohranjanje oziroma revitalizacijo slovenščine med slovensko manjšinsko skupnostjo v sosednjih državah (2016-2018), ki ga financirajo Javna agencija za raziskovalno dejavnost Republike Slovenije, Urad Vlade Republike Slovenije za Slovence v zamejstvu in po svetu ter Ministrstvo za izobraževanje, znanost in šport Republike Slovenije. 


\begin{tabular}{|c|c|c|c|c|c|c|c|}
\hline \multirow{2}{*}{\multicolumn{2}{|c|}{$\begin{array}{l}\begin{array}{l}\text { Druga gimnazija } \\
\text { županija) }\end{array} \\
\text { starši }(\mathbf{N}=\mathbf{3 9}) \\
\end{array}$}} & \multirow{2}{*}{$\begin{array}{l}\text { Varaždin }(V \\
\text { dijaki }(N=41)\end{array}$} & \multirow{2}{*}{$\begin{array}{l}\text { (Varaždinska } \\
\text { 1) } \\
\end{array}$} & \multicolumn{4}{|c|}{ Srednja šola Čakovec (Medžimurska županija) } \\
\hline & & & & \multicolumn{2}{|l|}{ starši $(N=18)$} & \multicolumn{2}{|c|}{ dijaki $(N=25)$} \\
\hline \multicolumn{8}{|l|}{ spol } \\
\hline ženski & 69,0 & ženski & 71,0 & ženski & 66,7 & ženski & 64,0 \\
\hline moški & 31,0 & moški & 27,0 & moški & 33,3 & moški & 36,0 \\
\hline brez odgovora & o & brez odgovora & 2,0 & & & & \\
\hline \multicolumn{8}{|c|}{ starostna struktura } \\
\hline do 30 let & 25,6 & 1. letnik & 9,8 & do 30 let & $\mathrm{o}$ & 1. letnik & $\mathrm{o}$ \\
\hline $31-40$ let & 64,1 & 2. letnik & 43,9 & $31-40$ let & 11,1 & 2. letnik & 60,0 \\
\hline $41-50$ let & 7,7 & 3. letnik & 19,5 & $41-50$ let & 77,8 & 3. letnik & 16,0 \\
\hline $51-60$ let & 2,6 & 4. letnik & 26,8 & $51-60$ let & 11,1 & 4. letnik & 24,0 \\
\hline nad 61 let & 2,6 & & & nad 61 let & o & & \\
\hline \multicolumn{8}{|c|}{ narodna pripadnost } \\
\hline hrvaška & 92,3 & hrvaška & 95 & hrvaška & 100,0 & hrvaška & 100,0 \\
\hline ruska & 5,1 & brez odgovora & 5 & & & & \\
\hline makedonska & 2,6 & & & & & & \\
\hline \multicolumn{8}{|l|}{ materni jezik } \\
\hline hrvaščina & 94,9 & hrvaščina & 100 & hrvaščina & 94,4 & hrvaščina & 100,0 \\
\hline ruščina & 5,1 & & & hrvaščina in & 5,6 & & \\
\hline \multicolumn{8}{|c|}{ izobrazbena struktura } \\
\hline osnovna šola & o & & & osnovna šola & 5,6 & & \\
\hline $\begin{array}{l}2-3 \text {-letna } \\
\text { strokovna šola }\end{array}$ & 10,3 & & & $\begin{array}{l}\text { 2-3-letna } \\
\text { strokovna šola }\end{array}$ & 22,2 & & \\
\hline $\begin{array}{l}\text { 4-letna } \\
\text { srednja šola }\end{array}$ & 82,1 & & & $\begin{array}{l}\text { 4-letna srednja } \\
\text { šola }\end{array}$ & 55,6 & & \\
\hline $\begin{array}{l}\text { višja, visoka ali } \\
\text { univerzitetna } \\
\text { izobrazba }\end{array}$ & 7,7 & & & $\begin{array}{l}\text { višja, visoka ali } \\
\text { univerzitetna } \\
\text { izobrazba }\end{array}$ & 16,6 & & \\
\hline
\end{tabular}

Tabela 1: Struktura anketiranih dijakov in staršev, ki so sodelovali v anketi v Varaždinski in Medžimurski županiji (izraženo v odstotkih).

Analiza anket je pokazala, da so se za učenje slovenščine odločili predvsem dijaki drugega in četrtega letnika, med katerimi prevladujejo dekleta. Med 
dijaki se nihče ni opredelil za pripadnika slovenske narodnosti in nihče ni navedel, da je njegov materni jezik slovenščina. Samo 1 dijak Druge gimnazije Varaždin je pri vprašanju o narodni pripadnosti dopisal, da je Hrvat $s$ slovenskimi koreninami.

Podobno so tudi med starši na anketo odgovorile večinoma ženske. Med starši dijakov Druge gimnazije Varaždin se jih je 92,3 \% opredelilo za hrvaško narodnost, 2 starša $(5,1 \%)$ sta navedla rusko narodnost in 1 starš $(2,6$ \%) je navedel makedonsko narodnost. Pri vprašanju o maternem jeziku je 94,9 \% staršev navedlo hrvaščino, 2 starša $(5,1 \%)$ pa sta navedla ruščino. Vsi starši dijakov Srednje šole Čakovec, ki so sodelovali v raziskavi, so se pri vprašanju o narodni pripadnosti opredelili kot Hrvati. Pri odgovorih o maternem jeziku je 1 starš (5,6 \%) navedel za materni jezik hrvaščino in slovenščino, ostalih 94,4 \% staršev pa je za materni jezik navedlo hrvaščino.

\section{IZSLEDKI RAZISKAVE, IZVEDENE MED DIJAKI IN NJIHOVIMI STAR ̌́ I}

Na podlagi odgovorov dijakov in njihovih staršev glede narodne pripadnosti in maternega jezika ni mogoče sklepati, da se pouka slovenščine $\mathrm{v}$ večjem številu udeležujejo pripadniki slovenske manjšine. $V$ anketi smo jim zastavili vprašanje odprtega tipa, in sicer zakaj so se odločili za učenje slovenskega jezika.

Odgovori dijakov dveh srednjih šol so se razlikovali. Med dijaki Druge gimnazije Varaždin je s 43,9 \% prevladoval odgovor, da se slovenščino učijo zaradi možnosti študija v Sloveniji, dijaki Srednje šole Čakovec pa so v največjem deležu (48 \%) odgovorili, da so se za učenje slovenščine odločili zaradi podobnosti obeh jezikov, slovenščine in hrvaščine. Ti odgovori morda kažejo na večjo ambicioznost dijakov Druge gimnazije Varaždin, ki v večji meri razmišljajo tudi o nadaljevanju šolanja $v$ tujini. Na Hrvaškem je študij $v$ Sloveniji dokaj priljubljen, saj naj bi diploma, pridobljena v tujini, imela na trgu dela večjo vrednost kot diploma, pridobljena na Hrvaškem. Študij v Sloveniji ima še nekatere druge prednosti. Pripadniki tako imenovane avtohtone 
slovenske narodne skupnosti $\mathrm{v}$ sosednjih državah in potomci slovenskih izseljencev lahko pridobijo štipendijo za študij prve ali druge stopnje v Republiki Sloveniji. Študenti, ki pridobijo takšno štipendijo, imajo načeloma tudi možnost subvencioniranega bivanja v študentskih domovih. Predvsem pa se lažje vpišejo na nekatere študijske smeri, na katere se na Hrvaškem ne bi mogli vpisati zaradi izjemno velike konkurence.

Tudi pri drugih odgovorih so se dijaki dveh srednjih šol bolj kot ne razlikovali (glej Sliko 1). V podobnem deležu (4-5 \%, kar dejansko pomeni 1-2 anketiranca) pa so dijaki obeh srednjih šol navedli, da se slovenščino učijo zato, ker imajo sorodnike v Sloveniji.

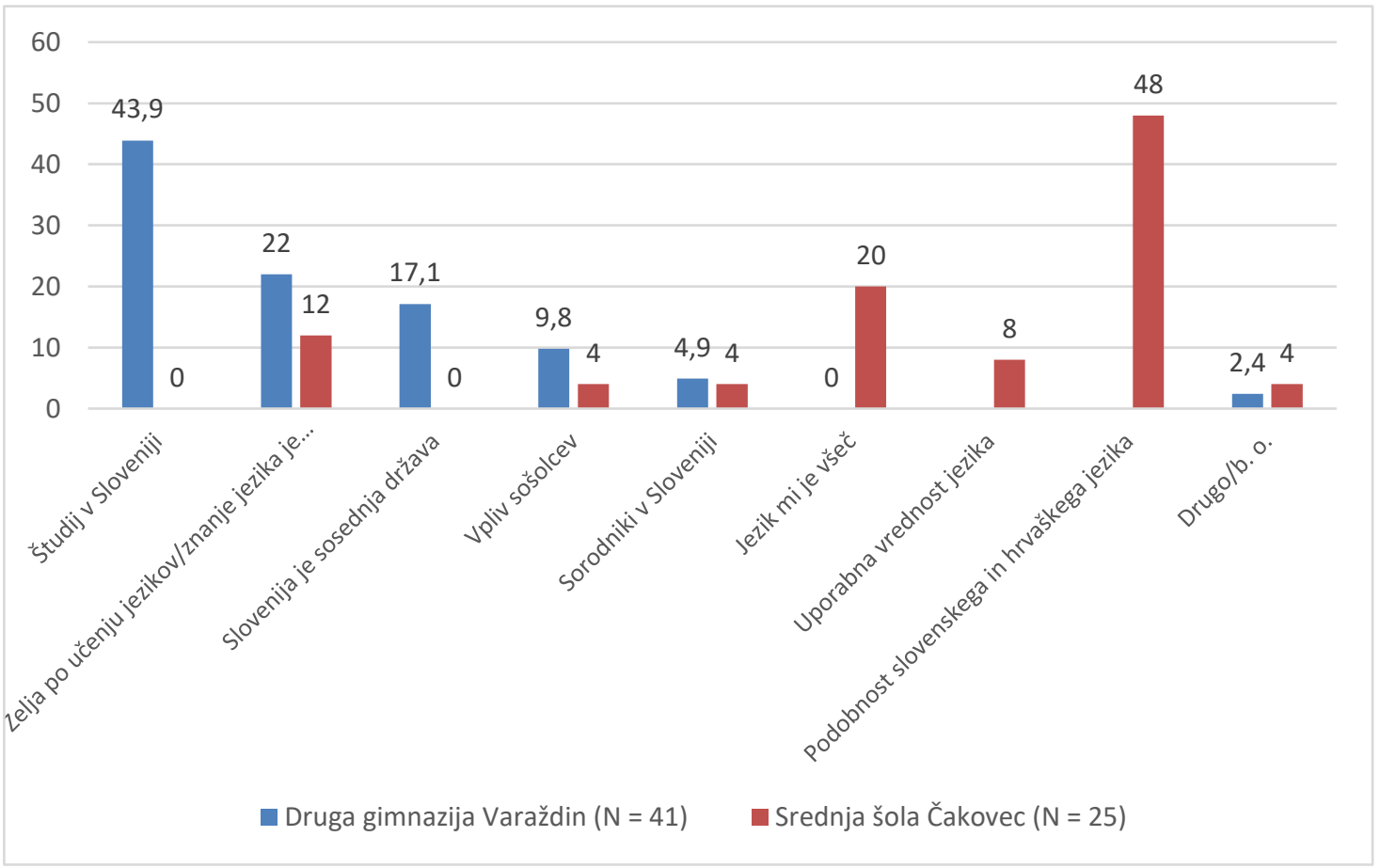

Slika 1: Odgovori dijakov Druge gimnazije Varaždin in Srednje šole Čakovec na vprašanje: »Zakaj si se odločil za učenje slovenskega jezika v šoli?« (izraženo v odstotkih).

Enako vprašanje smo zastavili staršem dijakov obeh srednjih šol in tudi njihovi 
odgovori so se razlikovali (glej Sliko 2). Starši dijakov Druge gimnazije Varaždin so v največjem deležu (51,3 \%) navedli, da bo učenje slovenščine povečalo možnosti za izobraževalno oziroma poklicno kariero otrok, medtem ko so starši dijakov Srednje šole Čakovec v največjem deležu (50 \%) navedli, da se je za učenje slovenščine odločil otrok sam. Samo 17,9 \% staršev, ki imajo dijake na Drugi gimnaziji Varaždin, je navedlo, da je učenje slovenskega jezika otrokova želja. Zanimivo je to, da je 11,1 \% staršev dijakov Srednje šole Čakovec navedlo, da se otroci učijo slovenski jezik, ker imajo sorodnike v Sloveniji, na drugi strani pa nihče izmed staršev dijakov Druge gimnazije Varaždin ni sorodnikov v Sloveniji navedel kot razlog za učenje slovenščine.

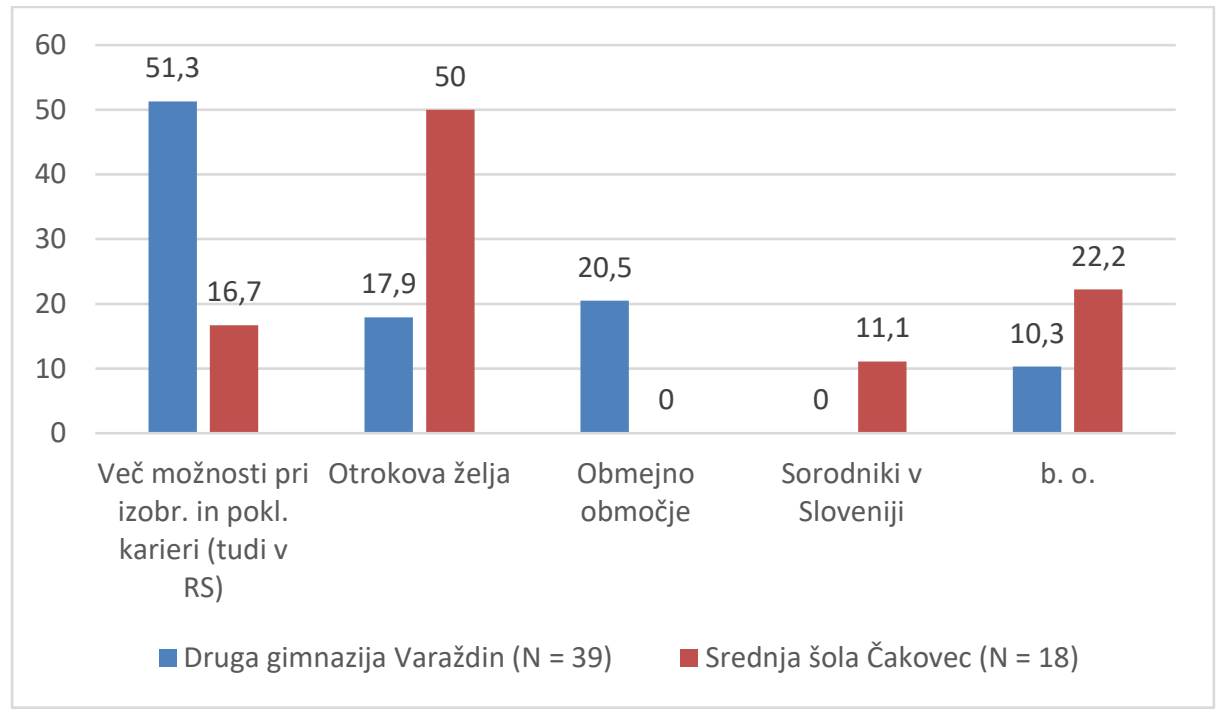

Slika 2: Odgovori staršev dijakov Druge gimnazije Varaždin in Srednje šole Čakovec na vprašanje: »Zakaj ste se odločili, da vaš otrok obiskuje pouk slovenskega jezika v šoli?« (izraženo v odstotkih).

Le majhno število dijakov in staršev je navedlo, da ima sorodnike v Sloveniji. Za dodaten vpogled $\mathrm{v}$ družinsko ozadje smo jih povprašali o rabi jezika $\mathrm{v}$ različnih govornih položajih, in sicer na dveh ravneh: v družini in zunaj nje.

Dijaki Druge gimnazije Varaždin v krogu družine večinoma uporabljajo 
hrvaščino. Majhno število dijakov pri komuniciranju z družinskimi člani poleg hrvaščine uporablja še kakšen drug jezik. 87,8 \% dijakov se z mamo pogovarja samo v hrvaščini in 82,9 \% se jih tudi z očetom pogovarja izključno v hrvaščini. Samo dijak, ki se je opredelil kot Hrvat s slovenskimi koreninami, v krogu družine z mamo, očetom, babico (po mamini strani) in družinskimi prijatelji komunicira delno $\mathrm{v}$ hrvaščini in delno $\mathrm{v}$ slovenščini.

2 dijaka sta še navedla, da se z mamo pogovarjata delno $\mathrm{v}$ hrvaščini in delno $\mathrm{v}$ ruščini, prav tako 2 dijaka se $\mathrm{z}$ mamo pogovarjata delno $\mathrm{v}$ hrvaščini in delno $\mathrm{v}$ nemščini, 1 dijak pa se $\mathrm{z}$ mamo pogovarja delno $\mathrm{v}$ hrvaščini in delno $\mathrm{v}$ portugalščini. Pri komuniciranju z očetom 1 dijak poleg hrvaščine uporablja še angleščino, 1 dijak poleg hrvaščine še nemščino in 1 dijak poleg hrvaščine tudi angleščino in nemščino. Pri komuniciranju s sestrami/brati je 7 dijakov navedlo, da poleg hrvaškega jezika uporabljajo še: angleščino (4 dijaki), angleščino in nemščino (1 dijak), angleščino in španščino (1 dijak) ter slovenščino (1 dijak). Tudi komuniciranje s starimi starši le pri manjšem številu dijakov poteka delno v hrvaškem in delno v kakem drugem jeziku, na primer nemščini (1 dijak), ruščini (2 dijaka), bosanščini (1 dijak) in slovenščini (2 dijaka). Podobno velja tudi za komuniciranje z družinskimi prijatelji. 8 dijakov je navedlo, da poleg hrvaščine uporabljajo še bodisi angleščino, nemščino, slovenščino, ruščino ali francoščino.

Odgovori dijakov Srednje šole Čakovec o rabi jezika v družini se niso veliko razlikovali. $\mathrm{Z}$ mamo se samo $\mathrm{v}$ hrvaščini pogovarja kar 92 \% dijakov, medtem ko se 2 dijaka pogovarjata $\mathrm{z}$ mamo delno $\mathrm{v}$ hrvaščini in delno $\mathrm{v}$ drugem jeziku, pri čemer pa je samo 1 dijak navedel, $v$ katerem - v angleščini. $Z$ očetom se samo $\mathrm{v}$ hrvaščini pogovarja 84 \% dijakov, 1 dijak se pogovarja $\mathrm{z}$ očetom delno $\mathrm{v}$ hrvaščini in delno $\mathrm{v}$ angleščini, prav tako 1 dijak delno $\mathrm{v}$ hrvaščini in delno $\mathrm{v}$ slovenščini ter 1 dijak delno v hrvaščini in delno v drugem jeziku, ni pa navedel, $\mathrm{v}$ katerem. $\mathrm{Z}$ brati in sestrami se samo 1 dijak pogovarja delno $\mathrm{v}$ hrvaškem in delno v slovenskem jeziku, ostali se vsi pogovarjajo samo v hrvaščini. Samo 1 dijak je še navedel, da se z babico - očetovo mamo - pogovarja delno v hrvaščini 
in delno v slovenščini, ostali dijaki se s svojimi starimi starši pogovarjajo izključno $\mathrm{v}$ hrvaščini. $\mathrm{Z}$ drugimi sorodniki se 1 dijak pogovarja samo $\mathrm{v}$ slovenščini ter 1 dijak delno v hrvaščini in delno v slovenščini, vsi ostali pa samo v hrvaščini.

Raba jezika v družini je v primerjavi z opredeljevanjem po narodni pripadnosti in maternem jeziku morda razkrila posameznika ali dva, za katera lahko predvidevamo, da imata slovenske prednike.

O pomislekih, s katerimi se sooča marsikateri pripadnik slovenske manjšine na Hrvaškem $\mathrm{v}$ povezavi $\mathrm{z}$ rabo slovenskega jezika $\mathrm{v}$ družini, je spregovorila intervjuvanka 1 (Varaždinska županija), ${ }^{21}$ ki je bila rojena v Sloveniji, vendar živi in dela na Hrvaškem:

Moja mama je Hrvatica, moj oče je Slovenec. /.../ Z mamo sem govorila hrvaško, z očetom slovensko. /.../ Ja, malo težje mi zdaj gre, ko svojega otroka poskušam ... težje je, no. Pa baje, vsi mi pravijo, da do tretjega leta naj ne bi otroku govorili v drugem jeziku ... Hm, ne vem, če je to res ali ni. Jaz tak skozi ne vem, pesmi in z branjem ter določene besede poskušam, no, z njim govoriti slovensko. Sem pa poskušala, če bi jaz samo slovensko govorila z njim, to pa zaenkrat ne gre. /.../ Jaz se ne morem z okoljem, v parku ali v vrtcu v slovenščini pogovarjati, ne ... Tak da jaz bom poskušala, če bo, bo, če pa ne, pa ... Ko bo sam, če se bo hotel učiti slovenščine, jaz bom vztrajala, ker mi je malo noro, da ne ve.

Srednja generacija, ki ima slovensko ozadje, velikokrat opusti rabo slovenščine ali pa le občasno uporablja slovenski jezik pri komuniciranju s svojimi otroki. Razlogov za to je zagotovo več, sklepamo pa lahko, da se najpogosteje, še posebej $\mathrm{v}$ javnih situacijah, ne želijo izrecno izpostavljati kot pripadniki manjšine.

Tudi zunaj družine se dijaki Druge gimnazije Varaždin večinoma pogovarjajo v hrvaškem jeziku. $\mathrm{V}$ posameznih govornih situacijah, na primer $\mathrm{v}$ pogovoru $\mathrm{s}$

${ }^{21}$ Pri projektu Priložnosti in možnosti za ohranjanje oziroma revitalizacijo slovenščine med slovensko manjšinsko skupnostjo v sosednjih državah (2016-2018) smo izvedli tudi nekaj intervjujev s pripadniki slovenske skupnosti. 
sosedi, sošolci, prijatelji zunaj šole ali v cerkvi, so posamezni dijaki navedli, da poleg hrvaščine uporabljajo še slovenščino, nemščino in angleščino. Zelo podobno so na to vprašanje odgovorili dijaki Srednje šole Čakovec, pri čemer je 1 dijak navedel, da se s sosedi, sošolci in prijatelji zunaj šole pogovarja delno $\mathrm{v}$ hrvaščini in delno $\mathrm{v}$ drugem jeziku, vendar ni napisal, $\mathrm{v}$ katerem. 1 dijak je napisal, da se s sošolci v šoli, s prijatelji zunaj šole in v kulturnem ali športnem društvu razen v hrvaščini pogovarja še v slovenščini in angleščini. 1 dijak pa je navedel, da se v kulturnem oziroma športnem društvu (vključen je v klub v Sloveniji) pogovarja delno $v$ hrvaščini in delno v slovenščini, in prav tako 1 dijak je navedel, da v kulturnem oziroma športnem društvu poleg hrvaščine uporablja tudi angleščino.

O pomenu rabe slovenščine zunaj družine je intervjuvanka 1 (Varaždinska županija) povedala:

Pa glejte, meni je fajn, ko se dobimo člani društva, pa se lahko pogovarjamo v slovenščini. Če bi jaz bila $500 \mathrm{~km}$ ali pa $5000 \mathrm{~km}$ stran, bi mi to verjetno več pomenilo. Jaz sem iz /kraj v Sloveniji, op. avt./, jaz sem za 15 minut doma.

Intervjuvanka je menila, da bi se slovenska skupnost morda bolj angažirala pri ohranjanju jezika in identitete, če ne bi živela ob meji s Slovenijo. Podatki popisov in izsledki raziskave kažejo ravno nasprotno, in sicer da se med slovensko skupnostjo na Hrvaškem slovenska identiteta in jezik celo bolje ohranjata v obmejnih županijah (med katere spadata tudi Varaždinska in Medžimurska županija) kot v notranjosti Hrvaške (Pajnič 2006: 226-227).

Raba slovenskega jezika kot uradnega jezika na Hrvaškem ni zagotovljena zaradi poselitvenih značilnosti in majhne številčnosti slovenske skupnosti. S tega vidika je prevladujoča raba hrvaškega jezika $\mathrm{v}$ javnem življenju logična posledica. Mladi, tudi če imajo znanje slovenskega jezika, nimajo veliko možnosti oziroma lahko le $\mathrm{v}$ redkih situacijah $\mathrm{v}$ javnem življenju slovenščino tudi uporabljajo. Pa vendar je kar zajeten delež dijakov obeh srednjih šol ocenil, da veliko prebivalcev županije, v kateri živijo, zna slovenski jezik (glej Slika 3). 


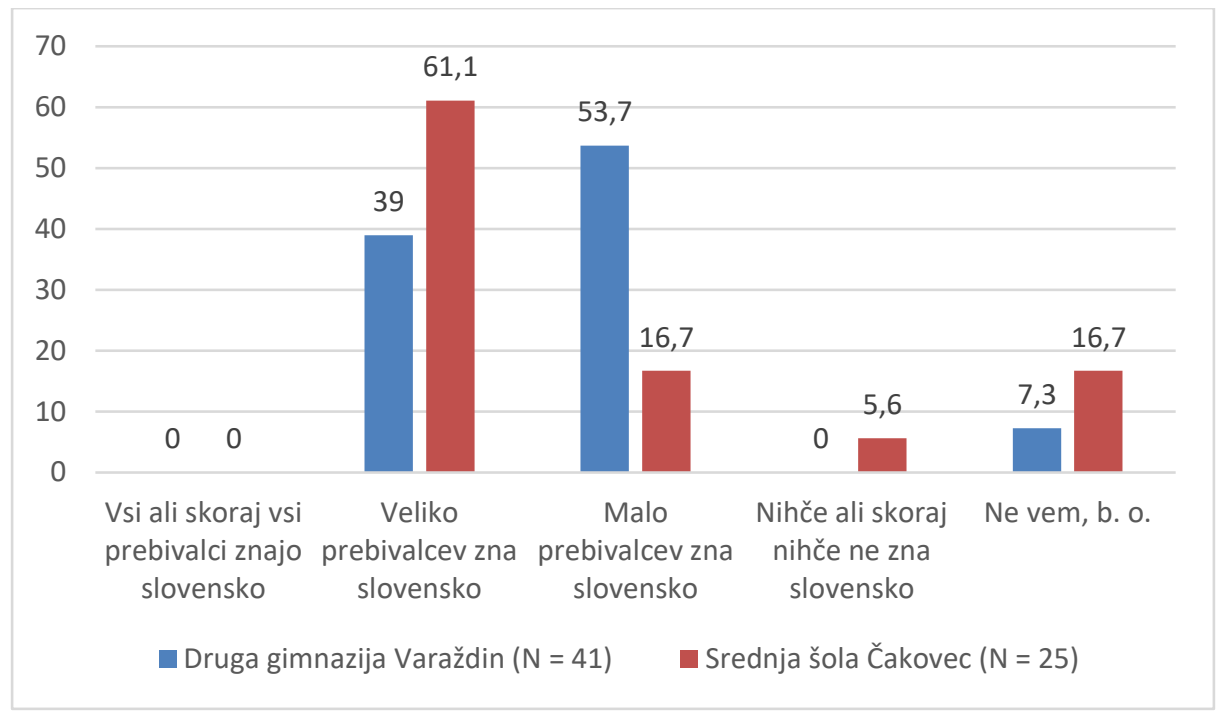

Slika 3: Odgovori dijakov na vprašanje: »Kako je znanje slovenskega jezika razširjeno med prebivalci županije, v kateri živiš? « (izraženo v odstotkih).

Kakšno je dejansko znanje slovenskega jezika med prebivalci Varaždinske in Medžimurske županije, je težko reči. Zagotovo pa obmejni položaj županije in življenje na obmejnem območju (v mnogih primerih vsakodnevno prehajanje meje zaradi dela, izobraževanja, preživljanja prostega časa itd.) vplivata na znanje jezika sosednje države in jezikovne vzorce prebivalcev. $\mathrm{K}$ »znanju« slovenskega jezika prebivalcev obmejnih območij prispevajo tudi mediji iz Slovenije. To nam je potrdila intervjuvanka 1, ki živi v Varaždinski županiji, saj je na vprašanje o vidnosti slovenskih medijev povedala:

Tukaj vsi gledamo slovensko televizijo, imamo Slovenijo 1, 2, 3, lokalne televizijske postaje, Planet tv. /.../ Če vprašate toliko stare kot jaz, bodo rekli, da so vsi gledali Pop tv in da oni vse razumejo v slovenščini; pogovarjati se sicer ne vejo, da pa razumejo. /.../ Mladi so bolj orientirani na angleščino, računalniki, mobiteli, te aplikacije so vse v angleščini, oni z deset let vejo toliko angleščine, kot sem jo jaz znala pri dvajsetih. Koliko bi oni bili zainteresirani za karkoli v slovenskem jeziku? 


\section{ZAKLJUČNA RAZMIŠLJANJA}

Slovenski skupnosti na Hrvaškem omogočata hrvaška in tudi slovenska zakonodaja različne možnosti učenja ter podporo pri ohranjanju slovenskega jezika. V Varaždinski in Medžimurski županiji se je predvsem zaradi angažiranja posameznih pripadnikov slovenske skupnosti v zadnjih nekaj letih veliko naredilo na področju učenja slovenskega jezika in vključevanja slovenščine $v$ redni šolski program.

Pokazalo pa se je, da se možnosti učenja slovenskega jezika trenutno bolj kot pripadniki slovenske skupnosti poslužujejo drugi prebivalci obmejnih županij. Mladi, ki se učijo slovenski jezik, in tudi njihovi starši izražajo pozitiven odnos do slovenščine kot jezika sosednje države ter se zavedajo, da znanje slovenskega jezika lahko prispeva $\mathrm{k}$ boljšim priložnostim za nadaljevanje izobraževanja ali zaposlitve v Sloveniji. Poudariti velja, da je zelo pomembno in pozitivno, da pripadniki večine prepoznajo slovenski jezik kot perspektivno izbiro in se ga tudi učijo, hkrati pa bi veljalo nameniti večjo pozornost iskanju razlogov, zakaj se pripadniki slovenske skupnosti v večjem številu ne vključujejo v organizirane oblike učenja slovenskega jezika. Ob upoštevanju popisnih podatkov o številu pripadnikov slovenske skupnosti v obravnavanih županijah in dejstva, da določeno število otrok obiskuje osnovno in srednjo šolo v Sloveniji, se postavlja vprašanje, koliko je sploh potomcev pripadnikov slovenske skupnosti, ki bi lahko obiskovali pouk slovenskega jezika.

Prebivalci obmejnih območij na Hrvaškem iz različnih razlogov, tudi dnevno, prehajajo mejo in imajo zaradi tega specifičen odnos do prebivalcev sosednje države. Ne glede na to so prebivalci slovenskega porekla na Hrvaškem v določenih situacijah »previdni«, »zadržani « in se ne želijo posebej izpostavljati kot pripadniki manjšine. Morda je tako tudi zaradi negativnega odnosa dela večinskega prebivalstva do manjšine v posameznih lokalnih okoljih $\square$ oziroma po besedah predstavnikov slovenske skupnosti zaradi prisotnosti splošne negativne klime do manjšin na Hrvaškem. 
Razlogov, zakaj slovenska skupnost ne uresničuje vseh pravic, ki so ji omogočene, je več; lahko jih iščemo tako na strani delovanja večine kot tudi slovenske skupnosti. Poudariti velja, da govorimo o pravicah manjšine in ne o avtomatičnih obveznostih države. Slovenska skupnost $\mathrm{v}$ preteklosti v marsikateri županiji ni bila organizirana in ni imela svojega društva. Obstoječe možnosti organiziranja, politične participacije in učenja slovenskega jezika so še vedno relativno nove pravice in njihovo uresničevanje $\mathrm{v}$ praksi zahteva angažiranost večjega dela skupnosti, ne samo nekaj posameznikov. K šibkejši samoiniciativnosti slovenske manjšine morda prispevata tudi slabša informiranost o obstoječih zakonodajnih možnostih, ki jih imajo v povezavi z organizacijo učenja slovenskega jezika v vzgojno-izobraževalnem sistemu, in nezadostna informiranost o pozitivnih učinkih večjezičnosti za posameznika, skupnost in celotno družbo. V vsakem primeru bi bila v prihodnosti dobrodošla večja in bolj množična angažiranost slovenske skupnosti.

\section{LITERATURA}

Beti, I. (2015): Da, izabrala sam - sebe! Večernji list, 13. 6. 2015. Dostopno prek: https://www.vecernji.hr/vijesti/da-izabrala-sam-sebe-1010234 (23. 8. 2017).

Državni zavod za statistiko Republike Hrvaške (2011): Stanovništvo prema narodnosti po gradovima/općinama, popis 2011. Dostopno prek: http://www.dzs.hr/Hrv/censuses/census2011/results/htm/Ho1_01_o 4/ho1_01_04_RH.html (17.6.2017).

Izbori 2015 za članove vijeća i predstavnike nacionalnih manjina (2015).

Dostopno prek:

http://www.izbori.hr/ws/index.html?documentId=626A9EoDBB3C75 2DC1257E4Boo26A526 (19. 9. 2016).

JPT (2015): Novi predstavniki slovenske manjšine v lokalni samoupravi. Novi odmevi. Zagreb: Kulturno prosvetno društvo Slovenski dom, 56. 
Koprivc, M. (2016): Analiza možnosti in izvajanja učenja slovenskega jezika $v$ slovenski skupnosti na Hrvaškem: Magistrsko delo. Ljubljana: Univerza v Ljubljani, Fakulteta za družbene vede.

Medvešek, M., in Riman, B. (2018): Znanje in raba slovenskega jezika med mladimi v slovenskem zamejstvu na Hrvaškem. V S. Novak Lukanovič (ur.): Mladi v slovenskem zamejstvu: družbeni in kulturni kontekst ter sodobni izzivi. Ljubljana: Inštitut za narodnostna vprašanja, Trst: SLORI, Celovec: Slovenski znanstveni inštitut, Slovenski narodopisni inštitut Urban Jarnik. (V tisku.)

Međimurska županija (2014): Slovenski ministar Gorazd Žmavc u radnom posjetu međimurskoj županiji, 10. 6. 2014. Dostopno prek: http://medjimurska-zupanija.hr/2014/o7/10/slovenski-ministargorazd-zmavc-u-radnom-posjetu-medimurskoj-zupaniji/ (9. 9. 2017).

Međimurska županija (2017): Suradnjom u pograničnom prostoru, međimurskim školarcima omogućeno besplatno učenje slovenskog jezika: Upravni odjel za društvene djelatnosti, 10. september 2017. Dostopno prek; http://medjimurskazupanija.hr/2017/o9/10/suradnjom-u-pogranicnom-prostorumedimurskim-skolarcima-omoguceno-besplatno-ucenje-slovenskogjezika/ (13. 10. 2017).

Mesarić, S. (2010): Na kraju spala knjiga na jedno slovo ... Međimurske novine, 20. 7. 2010: 9. Dostopno prek: http://issuu.com/mnovine/docs/mnovine776i/9 (7. 11. 2016).

Mesarić, S. (2012): Više se ne uči slovenski jezik, ali učenci opet odlaze u Sloveniju, Međimurske novine, 10. 2. 2012: 10-11. Dostopno prek: http://issuu.com/mnovine/docs/mnovine857i/10 (7. 11. 2016).

MZOS (Ministarstvo znanosti, obrazovanja i sporta) (2009): Izvješće o provođenju Ustavnog zakona o pravima nacionalnih manjina $i$ 
utrošku sredstava osiguranih u Državnom proračunu Republike Hrvatske za 2008. godinu za potrebe nacionalnih manjina, Vlada Republike Hrvatske Ured za nacionalne manjine, Ministarstvo znanosti, obrazovanja i športa, Zagreb, 4. 6. 2009. Dostopno prek: https://mzo.hr/sites/default/files/migrated/izvjesce-o-provodenjuustavnog-zakona.pdf.

MZOS (Ministarstvo znanosti, obrazovanja i sporta) (2012): Izvješće o provođenju Ustavnog zakona o pravima nacionalnih manjina $i$ utrošku sredstava osigurani u Državnom proračunu Republike Hrvatske za 2011 godinu, Vlada Republike Hrvatske Ured za nacionalne manjine, Ministarstvo znanosti, obrazovanja i športa, Zagreb, 17. 4. 2012. Dostopno prek: public.mzos.hr/fgs.axd?id=23272 (16. 11. 2016).

Pajnič, K. (2006): Struktura in položaj Slovencev na Hrvaškem: Magistrsko delo. Ljubljana: Univerza v Ljubljani, Filozofska fakulteta.

Resolucija o položaju avtohtonih slovenskih manjšin $v$ sosednjih državah in s tem povezanimi nalogami državnih in drugih dejavnikov Republike Slovenije (1996). Uradni list RS, št. 35-2280/1996.

Riman, B. (2013): Riječka Slovenka Zora Ausec i Slovenci u Rijeci nakon 1945. godine: »bratski narod « ili nacionalna manjina. V D. Roksandić in I. Cvijović Javorina(ur.): Intelektualci i rat 1939.-1947.: Zbornik radova s međunarodnog skupa Desničini susreti 2012: 363-378. Zagreb: FF press - Filozofski fakultet.

Srednja šola Čakovec (2016): Školski kurikulum Srednje škole Čakovec 2016./2017. Dostopno prek: http://ss-cakovec.skole.hr/upload/sscakovec/images/static3/1087/attachment/SKOLSKI_KURIKULUM__2016-17.pdf (16.11. 2016).

Strategija odnosov Republike Slovenije s Slovenci zunaj njenih meja (2016): 
sklep vlade Republike Slovenije 530oo-4/2016/4, 5. 5. 2016. Dostopno prek:

https://www.google.si/url?sa=t\&rct=j\&q=\&esrc $=s \&$ source $=w e b \& c d=4$ \&ved=oahUKEwj5uaTEwtzXAhXBJlAKHVc2DTcQFgg9MAM\&url=htt p\%3A\%2F\%2Fwww.uszs.gov.si\%2Ffileadmin\%2Fuszs.gov.si\%2Fpageu ploads\%2Fstrategija2016.doc\&usg=AOvVaw2Q8SAoyoWrZnqDJsjWtT gz (16. 11. 2016).

Škiljan, F. (2015): Slovenci u Varaždinu i Varaždinskoj županiji. Varaždin: Slovensko kulturno društvo Nagelj.

Tatalović, S. (2001): Nacionalne manjine u Republiki Hrvatskoj, Polit. misao, XXXVIII (3): 95-105.

Tatalović, S. (2005): Nacionalne manjine u Hrvatskoj. Split: STINE.

Tatalović, S., in Lacović, T. (2011): Prava manjinskih zajednica. Migracijske i etničke teme, 27 (3): 375-391.

Ustava Republike Slovenije (1991). Uradni list RS, št. 33/91-I, 42/97 UZS68, 66/oo - UZ8o, 24/o3 - UZ3a, 47, 68, 69/o4 - UZ14, 69/o4 UZ43, 69/o4 - UZ50, 68/o6 - UZ121,140,143, 47/13 - UZ148, 47/13 UZ9o,97,99 in 75/16 - UZ70a.

Ustavni zakon o človekovih pravicah in svoboščinah in pravicah narodnih in etničnih skupnosti ali manjšin v Republiki Hrvaški / Ustavni zakon o ljudskim pravima i slobodama i o pravima etničkih i nacionalnih zajednica ili manjina u Republici Hrvatskoj (1992). Narodne Novine, 34/1992.

Ustavni zakon o pravicah narodnih manjšin / Ustavni zakon o pravima nacionalnih manjina (2002). Narodne novine, 155/2002, 47/2010, $80 / 2010$ in $93 / 2011$.

Ustav Republike Hrvatske (1990). Narodne novine 56/1990, 135/1997, 8/1998, 113/2000, 124/2000, 28/2001, 41/2001, 55/2001, 76/2010, 
85/2010, 05/2014.

Ustav Socijalističke Federativne Republike Jugoslavije (1963). Dostopno prek: http://mojustav.rs/wp-content/uploads/2013/o4/Ustav-SFRJiz-1963.pdf (22. 5. 2017).

Ustav Socijalističke Federativne Republike Jugoslavije (1974). Dostopno prek: http://mojustav.rs/wp-content/uploads/2013/o4/Ustav-SFRJiz-1974.pdf (22. 5. 2017).

Ustav Socijalističke Republike Hrvatske (1974). Narodne novine, št. 8/1974. Dostopno prek:

https://www.pravo.unizg.hr/_download/repository/Ustav_Socijalistic ke_RH_1974.pdf (22.5.2017).

Vlada Republike Hrvatske (2015): Izvješće o provođenju ustavnog zakona o pravima nacionalnih manjina i o utrošku sredstava osiguranih $u$ državnom proračunu Republike Hrvatske za 2014. godinu za potrebe nacionalnih manjina. Dostopno prek:

https://pravamanjina.gov.hr/UserDocsImages/arhiva/27082015/Izvje sce_o_provedbi_UZPNM_za\%202014.pdf (16.11. 2016).

Zakon o predšolski vzgoji in izobraževanju / Zakon o predškolskom odgoju i obrazovanju (1997). Narodne novine, št. 10/97, 107/07, 94/13.

Zakonu o učbenikih $v$ osnovni in srednji šoli / Zakon o udžbenicima za osnovnu i srednju školu (2010). Narodne novine, št. 27/10, 57/11, $101 / 13$.

Zakon o uporabi jezika in pisave narodnih manjšin / Zakon o uporabi jezika i pisma nacionalnih manjina (2000). Narodne novine, št. 51/oo, $56 /$ oo.

Zakon o vzgoji in izobraževanju v jeziku in pisavi narodnih manjšin / Zakon o odgoju i obrazovanju na jeziku i pismu nacionalnih manjina (2000). Narodne novine, št. 51/oo, 56/oo. 
Zakon o vzgoji in izobraževanju v osnovni in srednji šoli / Zakon o odgoju i obrazovanju u osnovnoj i srednjoj školi (2008). Narodne novine, 87/08, 86/09, 92/10, 105/10, 90/11, 5/12, 16/12, 86/12, 126/12, 94/13, $152 / 14,07 / 17$.

Zakon o odnosih Republike Slovenije s Slovenci zunaj njenih meja (2006).

Uradni list RS, št. 43/2006 in 76/2010.

Zakon o ratifikaciji Sporazuma o sodelovanju $v$ kulturi in izobraževanju med Vlado Republike Slovenije in Vlado Republike Hrvaške (1994). Uradni list RS - Mednarodne pogodbe, št. 15/1994.

Zakonu o znanstveni dejavnosti in visokošolskem izobraževanju / Zakon o znanstvenoj djelatnosti i visokom obrazovanju (2003). Narodne novine, št. 123/03, 198/03, 105/04, 174/04, 02/07, 46/07, 45/09, $63 / 11,94 / 13,139 / 13,101 / 14,60 / 15$.

Združenje slovenska izseljenska matica (2016): Slovensko kulturno društvo Nagelj Varaždin. Dostopno prek: http://www.zdruzenjesim.si/seznam_drustev/1/2008112112362643/(15. 8. 2017).

Žitnik Serafin, J. (2014): Prerez zgodovine slovenskih kulturnih društev v jugoslovanskem prostoru. V J. Žitnik Serafin (ur.): Priseljevanje in društveno delovanje Slovencev $v$ drugih delih jugoslovanskega prostora: 137-179. Ljubljana: Založba ZRC, ZRC SAZU. 


\title{
THE INSTRUCTION OF SLOVENE AND THE ATTITUDES OF PUPILS AND PARENTS TOWARDS SLOVENE IN THE VARAŽDIN AND MEĐIMURJE COUNTIES IN CROATIA
}

\begin{abstract}
In the last five years, new options for learning the Slovene language in schools have been realized in the counties of Varaždin and Medžimurje. The article deals with legal options concerning the regulation of the status of Slovene language in Croatia, with the implementation of options of learning Slovene in the counties of Varaždin and Medžimurje, as well as with results of research studies on learning Slovene, performed amongst students of two secondary schools and their parents. According to the results, students and parents have a positive attitude towards learning Slovene. Command of Slovene is especially important for them, in terms of better chances for schooling and employment in Slovenia. It also turned out that there are few members of the Slovene minority amongst pupils learning Slovene.
\end{abstract}

Keywords: Slovene language, Varaždin county, Medžimurje county, Croatia, minority language learning

To delo je ponujeno pod licenco Creative Commons: Priznanje avtorstvaDeljenje pod enakimi pogoji 4.o Mednarodna.

This work is licensed under the Creative Commons Attribution-ShareAlike 4.0 International.

https://creativecommons.org/licenses/by-sa/4.o/

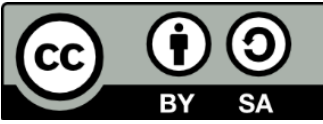

